\title{
Pengaruh Penerapan Model Problem Based Learning terhadap Kemampuan Pemecahan Masalah Matematika Siswa
}

\author{
Rini Sri Putri ${ }^{*}$, Mulia Suryani², dan Lucky Heriyanti Jufri ${ }^{3}$ \\ $1^{*, 2,3}$ Program Studi Pendidikan Matematika, STKIP PGRI Sumbar \\ Jalan Gunung Pangilun, Padang, Sumatera Barat, Indonesia \\ 1*rini_sriputri@yahoo.co.id
}

Artikel diterima: 25-03-2019, direvisi: 30-05-2019, diterbitkan: 31-05-2019

\begin{abstract}
Abstrak
Penelitian bertujuan untuk mengetahui bagaimana pengaruh penerapan model problem based learning terhadap kemampuan pemecahan masalah matematika siswa kelas VII SMP Negeri 3 Palembayan berdasarkan tingkat Kemampuan Awal Matematis (KAM) siswa. Dimana siswa dibagi menjadi 3 kategori yaitu KAM Tinggi, KAM Sedang dan KAM rendah. Jenis penelitian yang digunakan dalam penelitian ini adalah penelitian pre-eksperimen, dengan rancangan penelitian one shot case study. Subjek pada penelitian ini siswa kelas VII.3 yang dipilih secara secara acak. Instrumen yang digunakan pada penelitian ini adalah tes akhir. Tes yang digunakan adalah berbentuk essay. Penelitian ini menggunakan teknik analisis data deksriptif kualitatif. Berdasarkan analisis data secara keseluruhan, model PBL dapat membuat kemampuan pemecahan masalah matematika siswa lebih baik. Terlebih lagi untuk siswa yang termasuk ke dalam kategori KAM tinggi. Ini terlihat dari ukuran pemusatan dimana rata-rata untuk siswa pada kategori sedang 52,86 dengan simpangan baku 11,31 sehingga disimpulkan bahwa model ini dapat memberikan pengaruh terhadap kemampuan pemecahan masalah siswa.

Kata Kunci: Problem Based Learning, Kemampuan Pemecahan Masalah, KAM, Kemampuan Awal Matematis.

\section{The Effect of Application of the Problem Based Learning Model on Mathematical Problem Solving Students}

Abstract

This study aimed to determine how the effect of problem-based learning model implementation toward student mathematic problem-solving abilities at Class VII SMPN 3 Palembayan based on the basic level of Mathematical Ability. Students were divided into 3 categories such as the low, medium and high ability. It was pre-experimental research using one shot case research study design. The research subject was class VII.3 students who were randomly selected. The instrument was a final test in the form of an essay. It used a qualitative descriptive data analysis technique. Based on the data analysis, the Problem-solving learning model can make students' mathematics problem-solving abilities better. Moreover, those students are categorized into high ability. It is seen from the concentration measure for students in the medium category are 52.86 with a standard deviation i.e. 11.31. It is concluded that problem-solving model can affect the students' problem-solving abilities.

Keywords: Problem Based Learning, Problem Solving Ability, Basic Mathematical Ability.
\end{abstract}




\section{Pendahuluan}

Utami dan Wutsqa (2017) mengatakan bahwa matematika merupakan salah satu mata pelajaran yang wajib dipelajari oleh siswa pada setiap jenjang pendidikan. Pentingnya matematika tidak hanya dipelajari di dalam kelas, namun matematika dekat dengan kegiatan seharihari.

Menurut Nikson dalam Muliyardi (2002) "Pembelajaran matematika adalah upaya untuk membantu siswa untuk mengkontruksi konsep-konsep atau prinsip-prinsip matematika dengan kemampuannya sendiri melalui proses internalisasi sehingga konsep atau prinsip itu terbangun kembali". Salah satu kemampuan matematis yang harus dimiliki siswa adalah kemampuan pemecahan masalah matematika. (Utami \& Wutsqa, 2017), kemampuan pemecahan masalah menjadi salah satu tujuan pembelajaran matematika yang harus dicapai oleh siswa yang terdapat pada Peraturan Menteri Pendidikan Nasional No 22 Tahun 2006.

Adapun pendapat lain menurut Jones (Budiyono, 2005) terdapat beberapa alasan perlunya kemampuan pemecahan dalam membangun suatu konsep dan berfikir matematis serta untuk memiliki pemahaman masalah yang kuat. Selanjutnya, menurut (Gunantara, Suarjana, \& Riastini, 2014) kemampuan pemecahan masalah merupakan kecakapan atau potensi yang dimiliki siswa dalam menyelesaikan permasalahan dan masalah yaitu memberi kelancaran siswa

mengaplikasikannya dalam kehidupan sehari-hari.

Ada dua studi internasional yang mengukur kemampun pemecahan masalah siswa yaitu Trends in International Mathematics and Science Study (TIMSS) dan Program for International Student Assessment (PISA). Hasil uji TIMSS pada tahun 2015, Indonesia berada pada peringkat 44 dari 49 negara peserta dengan nilai 386. Sedangkan hasil uji PISA, Indonesia berada pada peringkat 63 dari 64 negara peserta dengan nilai 386. Skor rerata internasional untuk TIMSS dan PISA adalah 500. Kedua hasil uji studi membuktikan bahwa Indonesia menduduki posisi di bawah rata-rata, yang mana kemampuan pemecahan masalah matematika siswa masih rendah yang disebabkan beberapa faktor. Salah satunya, kurang berlatih dalam menyelesaikan soal-soal yang non rutin (Afriansyah, 2016). Oleh karena itu, guru perlu meninjau kembali pembelajaran matematika agar dapat menghasilkan kemampuan pemecahan masalah siswa sesuai dengan yang diharapkan.

Pengembangan ide dan pemecahan masalah siswa masih rendah. Kenyataannya juga ditemukan di SMP Negeri 3 Palembayan Kabupaten Agam menunjukkan kemampuan pemecahan masalah matematika siswa belum sesuai dengan apa yang diharapkan. Misalnya guru memberikan contoh soal serta penyelesaiannya kemudian saat guru memberikan contoh soal yang kedua yang akan diselesaikan oleh siswa, mereka tidak 
dapat mengerjakan soal tersebut karena sedikit berbeda dari contoh soal nomor satu. Akibatnya, kemampuan pemecahan masalah matematika siswa tidak diaplikasikan secara optimal.

Berdasarkan gambar 1, terlihat bahwa soal tidak dapat dipecahkan atau diselesaikan dengan benar. Soal tersebut menanyakan luas lahan yang digunakan untuk taman, yang mana langkah pertama jumlahkan 2 pecahan yang diketahui dengan menyamakan penyebutnya terlebih dahulu kemudian dikali dengan luas lahan. Penyelesaian $1-\left(\frac{1}{3}+\frac{1}{4}\right)=$ $1-\left(\frac{4}{12}+\frac{3}{12}\right)=1-\frac{7}{12}=\frac{5}{12}$. Jadi, luas lahan yang digunakan Pak Karta adalah $\frac{5}{12} \times 360 \mathrm{~m}^{2}=150 \mathrm{~m}^{2}$.

Salah satu model pembelajaran yang dapat meningkatkan kemampuan pemecahan masalah matematika siswa adalah Problem Based Learning (Fatimah, 2012). Menurut Arends dalam Suprihatiningrum (2013), PBL merupakan suatu pendekatan pembelajaran, yang mana siswa mengerjakan permasalahan yang otentik dengan maksud untuk menyusun pengetahuan mereka sendiri, mengembangkan inkuiri dan keterampilan berpikir tingkat lebih tinggi,

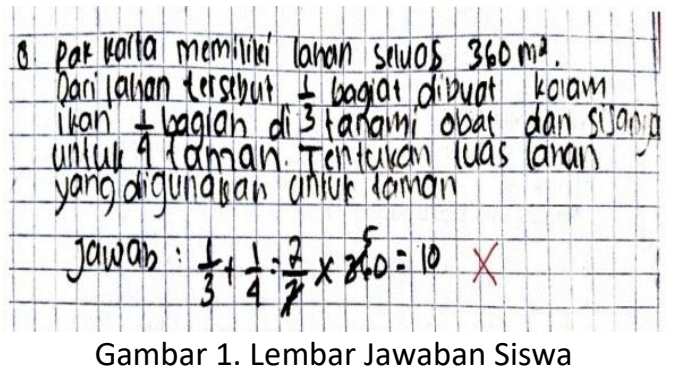

Gambar 1. Lembar Jawaban Siswa mengembangkan kemandirian dan percaya diri. Dimana suatu model pembelajaran ini, dimulai dengan siswa dihadapkan pada suatu masalah kemudian diikuti oleh proses pencarian informasi yang bersifat student center.

Menurut Tan (Rusman, 2013) PBL merupakan inovasi dalam pembelajaran karena dalam PBL kemampuan berfikir siswa betul-betul dioptimalisasikan melalui proses kerja kelompok atau tim yang sistematis, sehingga siswa dapat memberdayakan, mengasah, menguji, dan mengembangkan kemampuan berfikirnya secara berkesinambungan.

Menurut Ibrahim dalam Suprihatiningrum (2013) mengemukakan bahwa sintak PBL adalah sebagai berikut:

a. Fase 1 (Orientasi siswa kepada masalah). Menjelaskan tujuan pembelajaran menjelaskan logistik yang dibutuhkan dan memotivasi siswa untuk terlibat aktif dalam pemecahan masalah yang dipilih.

b. Fase 2 (Mengorganisasikan siswa kepada masalah). Membantu siswa mendefinisikan dan mengorganisasikan tugas belajar yang berhubungan dengan masalah tersebut.

c. Fase 3 (Membimbing penyelidikan individu dan kelompok). Mendorong siswa untuk mengumpulkan informasi yang sesuai, melaksanakan eksperimen untuk mendapatkan penjelasan dan pemecahan masalah.

d. Fase 4 (Mengembangkan dan menyajikan hasil karya). Membantu siswa dalam merencanakan dan menyiapkan karya yang sesuai seperti 
laporan, model dan berbagi tugas dengan teman.

e. Fase 5 (Menganalisa dan mengevaluasi proses pemecahan masalah). Mengevaluasi hasil belajar tentang materi telah dipelajari/meminta kelompok presentasi hasil karya.

Sebuah masalah timbul ketika terdapat "Situasi dimana seseorang mencoba mencapai beberapa tujuan dan harus menemukan cara untuk sampai di sana" (Chi \& Glaser, 1985). Pemecahan masalah mengacu pada usaha orang-orang untuk mencapai tujuan karena mereka tidak memiliki solusi otomatis. Masalah memiliki tujuan yaitu apa yang coba didapatkan si pemecah masalah untuk pencapaian tujuan.

Pemecahan masalah merupakan suatu proses untuk mengatasi kesulitankesulitan yang dihadapi untuk mencapai tujuan yang diharapkan. Dalam matematika, kemampuan pemecahan masalah harus dimiliki oleh siswa untuk menyelesaikan soal-soal berbasis masalah. Dalam (Sundayana, 2016) Pentingnya kemampuan pemecahan masalah dikemukakan oleh Branca (Krulik dan Rays, 1980), yaitu: (1) kemampuan pemecahan masalah merupakan tujuan umum pengajaran matematika, bahkan sebagai jantungnya matematika, (2) pemecahan masalah dapat meliputi metode, prosedur dan strategi atau cara yang digunakan merupakan proses inti dan utama dalam kurikulum matematika, dan (3) pemecahan masalah merupakan kemampuan dasar dalam belajar matematika. Dari hal tersebut, melalui pemecahan masalah, siswa akan terbiasa dan mempunyai kemampuan dasar yang lebih bermakna dalam berpikir, dan dapat membuat strategi-strategi penyelesaian untuk masalah-masalah selanjutnya.

Menurut Jones (Budiyono, 2005) dalam (Sumartini, 1981) terdapat beberapa alasan perlunya kemampuan pemecahan masalah yaitu memberi kelancaran siswa dalam membangun suatu konsep dan berfikir matematis serta untuk memiliki pemahaman masalah yang kuat.

Polya (Amir, 2015) mengemukakan langkah-langkah pemecahan masalah, yaitu:

1) Memahami masalah.

Kegiatan dapat yang dilakukan pada langkah ini adalah apa (data) yang diketahui, apa yang tidak diketahui (ditanyakan), apakah informasi cukup, kondisi (syarat) apa yang harus dipenuhi, menyatakan kembali masalah asli dalam bentuk yang lebih operasional (dapat dipecahkan).

2) Merencanakan pemecahannya. Kegiatan yang dapat dilakukan pada langkah ini adalah: mencoba mencari atau mengingat masalah yang pernah diselesaikan yang memiliki kemiripan dengan masalah yang akan dipecahkan, mencari pola atau aturan, menyusun prosedur penyelesaian.

3) Menyelesaikan masalah sesuai rencana.

Kegiatan yang dapat dilakukan pada langkah ini adalah: menjalankan prosedur yang telah dibuat pada langkah Mosharafa: Jurnal Pendidikan Matematika Volume 8, Nomor 2, Mei 2019 Copyright $\odot 2019$ Mosharafa: Jurnal Pendidikan Matematika 
sebelumnya untuk mendapatkan penyelesaian.

4) Memeriksa kembali prosedur dan hasil penyelesaian.

Kegiatan yang dapat dilakukan pada langkah ini adalah menganalisis dan mengevaluasi apakah prosedur yang diterapkan dan hasil yang diperoleh benar, atau apakah prosedur dapat dibuat generalisasinya.

Pada proses pembelajaran, beberapa siswa mengalami kesulitan dalam mengamati maupun memahami pelajaran matematika. Mereka menganggap matematika itu sulit. Contohnya pada saat mengerjakan soal latihan, mereka kurang mampu menyelesaikan soal-soal non rutin sehingga proses yang mereka lakukan tidak mendapatkan hasil kerja yang tepat dan membuat mereka malas untuk menyelesaikan soal tersebut. Pada defenisi PBL yaitu proses pembelajaran yang berbasis pada penyelesaian masalah. Maka penelitian ini bertujuan untuk mengetahui bagaimana pengaruh penerapan model PBL terhadap kemampuan pemecahan masalah matematika siswa kelas VII SMP Negeri 3 Palembayan berdasarkan tingkat Kemampuan Awal Matematika (KAM) siswa. KAM ini digunakan untuk mengetahui gambaran mengenai kemampuan awal matematis siswa sebelum penelitian dilakukan atau sebelum perlakuan diberikan. Di samping itu, data KAM ini juga digunakan untuk siswa dikelompokkan berdasarkan kemampuan awalnya yaitu tinggi, sedang dan rendah.

\section{Metode}

Metode yang digunakan dalam penelitian ini adalah pre-eksperimen. Arikunto (2010) bahwa "Penelitian Preexperimental seringkali dipandang sebagai eksperimen yang tidak sebenarnya atau sering disebut dengan istilah quasi experiment atau eksperimen pura-pura." Pre-eksperimen dengan rancangan penelitian yaitu random sampling terhadap subjek. Populasi penelitian ini adalah seluruh kelas VII SMP Negeri 3 Palembayan, yang terpilih sebagai kelas sampel adalah kelas VII.3 yang berjumlah 26 siswa.

\section{Variabel Penelitian}
a. Variabel Bebas (X): Model pembelajaran Problem Based Learning

b. Variabel Terikat (Y): Kemampuan pemecahan masalah matematika

\section{Desain Penelitian}

Adapun desain dalam penelitian ini adalah one shot case study (Sugiyono, 2011), dapat dilihat pada gambar 2 .

Teknik analisis data yang digunakan

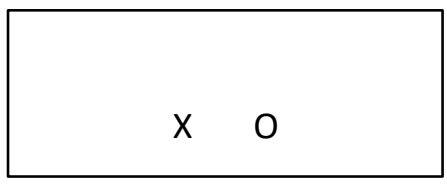

Gambar 2. One Shot Case Study.

Keterangan

$X$ : Perlakuan terhadap kelompok eksperimen yaitu dengan menggunakan model PBL

O : Observasi (Variabel Dependen) 
yaitu analisis data deskriptif kualitatif. Menurut penelitian yang dilakukan oleh Iskandar (2009), menyatakan bahwa penelitian deskriptif merupakan penelitian untuk memberi uraian mengenai fenomena atau gejala sosial yang diteliti dengan mendeskripsikan tentang nilai variabel mandiri, baik satu variabel atau lebih berdasarkan indikator-indikator dari variabel yang diteliti tanpa membuat perbandingan atau menghubungkan antara variabel yang diteliti guna untuk eksplorasi dan klasifikasi dengan mendeskripsikan sejumlah variabel yang berkenaan dengan masalah variabel yang diteliti.

Pada saat penelitian siswa dibagi kelompok berdasarkan KAM (tinggi, sedang, rendah). Didapatkan siswa yang kategori KAM tinggi ada 4 orang, kategori KAM sedang 19 orang dan kategori KAM rendah 3 orang (lihat tabel 1).

Berdasarkan analisis data, model PBL terhadap kemampuan pemecahan masalah dapat memberikan pengaruh terhadap siswa.

\section{Hasil dan Pembahasan}

Berdasarkan penelitian yang telah Tabel 1.

Pengelompokkan Siswa berdasarkan KAM

\begin{tabular}{|cc|}
\hline Kriteria & Kategori \\
\hline$x \geq \bar{x}+\mathrm{SB}$ & Tinggi \\
\hline $\bar{x}-\mathrm{SB}<x<\bar{x}+\mathrm{SB}$ & Sedang \\
\hline $\bar{x}-\mathrm{SB} \geq x$ & Rendah \\
\hline
\end{tabular}

Keterangan:

$$
\begin{array}{ll}
x & =\text { nilai siswa } \\
\bar{x} & =\text { rata-rata skor / nilai siswa } \\
\mathrm{SB} & =\text { simpangan baku dari skor / nilai siswa }
\end{array}
$$

dilakukan pada tanggal 10 - 28 Januari 2019 sebanyak 5 pertemuan. pertemuan 1 pembelajaran selama 120 menit, pertemuan 2 pembelajaran selama 80 menit, pertemuan 3 pembelajaran selama 120 menit, pertemuan 4 pembelajaran selama 80 menit dan pertemuan 5 dilakukan tes akhir berupa soal esai sebanyak 5 soal yang dilakukan selama 100 menit yang diikuti oleh siswa sebanyak 24 orang (lihat tabel 2)

Berdasarkan tabel 2, nilai tes akhir siswa berdasarkan kemampuan pemecahan masalah secara keseluruhan nilai siswa berada mendekati rata-rata.

Pada tes akhir dapat dilihat kemampuan pemecahan masalah KAM rendah dan KAM sedang dapat dilihat pada tabel 3.

Hasil analisis data model PBL terhadap kemampuan pemecahan masalah paling

Tabel 2.

Rata-rata Kemampuan Pemecahan Masalah

\begin{tabular}{lcccc}
\multicolumn{5}{c}{ Matematika Siswa } \\
\hline \multicolumn{1}{c}{ Tes } & $\overline{\boldsymbol{X}}$ & SB & $\boldsymbol{X}_{\text {Maks }}$ & $\boldsymbol{X}_{\text {Min }}$ \\
\hline Tes & 92,92 & 13,50 & 100 & 40 \\
Akhir & & & \\
$\overline{\boldsymbol{X}} \quad$ : & rata-rata nilai tes akhir \\
SB $\quad$ : simpangan baku tes akhir \\
$\boldsymbol{X}_{\text {Maks }}$ : & nilai maksimal siswa \\
$\boldsymbol{X}_{\text {Min }}$ : & nilai minimum siswa
\end{tabular}

Tabel 3.

Rekapitulasi Kemampuan Pecahan Masalah

\begin{tabular}{ccccc}
\hline $\mathbf{T}$ & $\overline{\boldsymbol{X}}$ & $\overline{\boldsymbol{X}}$ & $\boldsymbol{S B}$ & $\boldsymbol{S B}$ \\
$\mathbf{e}$ & KAM & KAM & KAM & KAM \\
$\mathbf{S}$ & Rdh & Sdg & Rdh & Sdg \\
\hline Tes & 30 & 52,86 & 2,91 & 11,31 \\
Ak- & & & & \\
hir & & & & \\
& & & &
\end{tabular}

Mosharafa: Jumal Pendidikan Matematika Volume 8, Nomor 2, Mei 2019 Copyright @ 2019 Mosharafa: Jurnal Pendidikan Matematika 
memberikan pengaruh terhadap siswa yang kategori KAM tinggi seperti tabel 1 . Karena telihat pada siswa KAM tinggi merasa tertantang dan lebih sangat bersemangat melakukan proses pembelajaran yang di awali dengan soal pemecahan masalah yang mana siswa memahami masalah terlebih dahulu, membuat dugaan atau perencanaan masalah, menyelesaikan masalah kemudian memeriksa kembali hasil masalah tersebut. Akan tetapi PBL terhadap pemecahan masalah tidak cocok pada siswa KAM rendah karena mereka sulit mengikuti pembelajaran tanpa dijelaskan terlebih dahulu oleh guru. Sedangkan siswa KAM sedang, sebagian sama dengan siswa berkemampuan tinggi. Sehingga hasil ujian terhadap kemampuan pemecahan masalah meningkat dari sebelumnya.

Pada diskusi kelompok siswa kesulitan memahami masalah yang terdapat pada lembar diskusi. Kemudian guru membantu siswa mengarahkan untuk dapat menemukan masalah pada soal. Siswa KAM tinggi dapat menemukan masalah walaupun kesulitan di awal. Begitu juga dengan siswa KAM sedang mereka sulitan memahami masalah. Siswa KAM rendah tidak memahami masalah dan takut bertanya. Kemudian siswa membuat rencana untuk menyelesaikan masalah. Siswa awalnya bingung pada tahap ini, kemudian dijelaskan guru baru mereka paham tahap apa yang harus diselesaikan. Guru mendorong siswa untuk mencari informasi dari berbagai sumber, misalnya buku pegangan siswa ataupun buku matematika lain yang dipinjam dari perpustakaan. Siswa menyelesaikan masalah dengan membuat rencana yang akan diselesaikan dan melakukan perhitungan dengan benar. Sebagian siswa ada belum lengkap penyelesaian dan perhitungannya yang salah. siswa tersebut disuruh untuk memperbaiki lembar diskusinya dengan jawaban yang benar. Tahap akhir siswa membuat kesimpulan atau memeriksa kembali hasil diskusinya.

Kemampuan siswa menjawab dalam lembar jawabannya dengan tahapan pemecahan masalah sebagai berikut:

a. Memahami Masalah

Pada tahapan ini siswa memahami masalah yang dan mengidentifikasi soal apa saja yang diketahui dan ditanya. Siswa KAM tinggi telah mampu menemukan masalah dengan benar. Begitupun siswa KAM sedang telah menemukan masalah dengan benar. Siswa KAM rendah sebagian menemukan masalah pada soal tetapi tidak lengkap.

Berdasarkan gambar 3, siswa KAM tinggi telah mampu mengindentikasi dan memahami soal serta menemukan apa yang diketahu dan tanya. Begitupun pada siswa KAM sedang juga sama dengan KAM tinggi (lihat gambar 4).

Berdasarkan gambar 5, siswa KAM

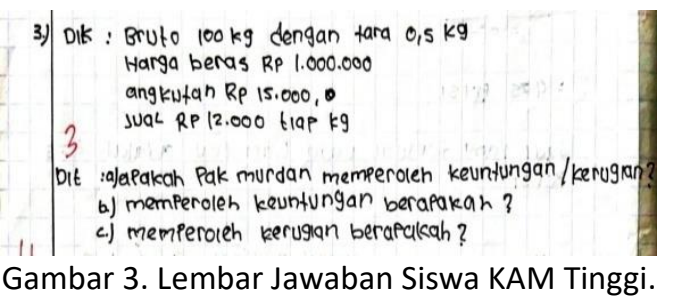


rendah hanya sedikit memahami soal dan tidak menemukan apa yang ditanya pada soal. Jadi KAM rendah masih ketinggalan dari KAM tinggi dan sedang.

\section{b. Merencanakan Masalah}

Tahapan merencanakan masalah siswa merasa ragu dan kesulitan pada awalnya. Akan tetapi pada saat tes akhir siswa KAM tinggi dan sedang mampu membuat rencana atau dugaan dengan benar. Siswa KAM rendah melakukan 1 rencana dengan benar tetapi tidak ada lain yang akan diselesaikan.

Berdasarkan gambar 6, siswa KAM tinggi telah mampu membuat rencana untuk menyelesaikan permasalahan dengan benar. Begitupun dengan KAM sedang telah mampu memahami soal.

Berdasarkan gambar 7, siswa KAM sedang telah mampu membuat rencana atau dugaan untuk menyelesaikan

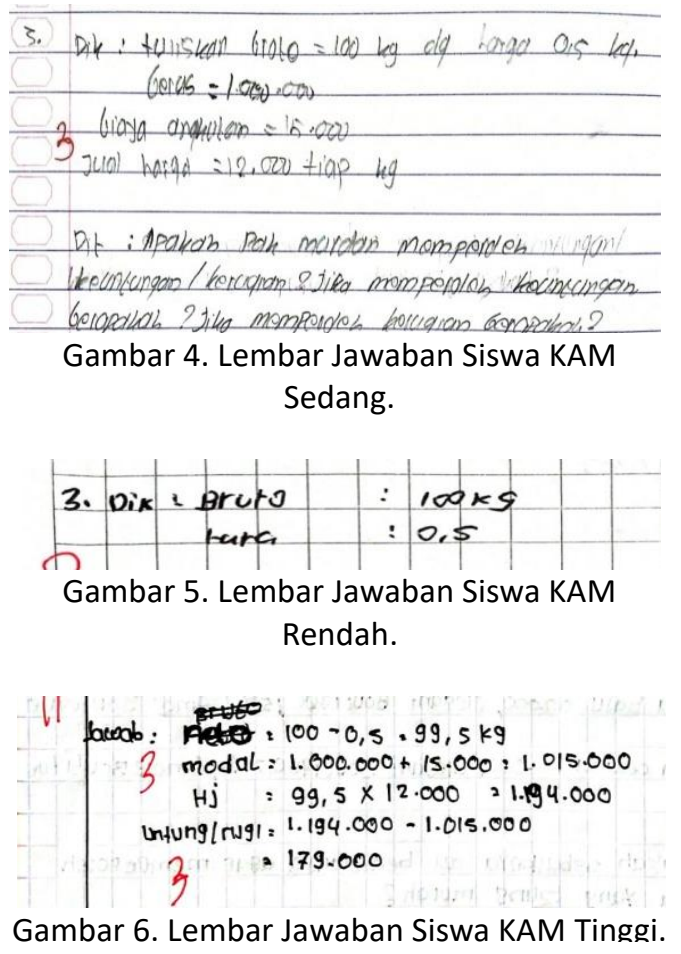

masalah. Akan tetapi KAM rendah masih kurang lengkap tahap perencanaannya (lihat gambar 8).

Berdasarkan gambar 8, siswa KAM rendah mampu membuat rencana atau dugaan untuk menyelesaikan masalah meskipun kurang lengkap.

c. Menyelesaikan Masalah

Tahapan menyelesaikan masalah siswa dengan mudah melakukan karena rencana atau dugaan telah dibuat dengan benar. Jadi siswa mengikuti prosedur yang ada. Siswa KAM tinggi dan sedang telah mampu melakukan tahapan ini dengan benar. Siswa KAM rendah melakukan 1 penyelesaian dengan benar tetapi tidak lengkap atau belum selesai dengan tahapan berikutnya (lihat gambar 9).

Berdasarkan gambar 9, siswa KAM tinggi telah mampu menyelesaikan masalah dengan benar dan tepat sesuai dengan prosedur yang ada. Begitupun KAM sedang telah mampu melakukan

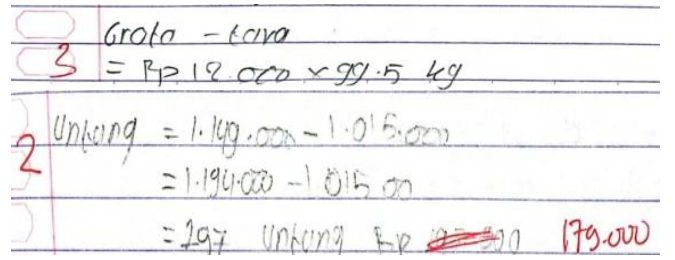

Gambar 7. Lembar Jawaban Siswa KAM Sedang.

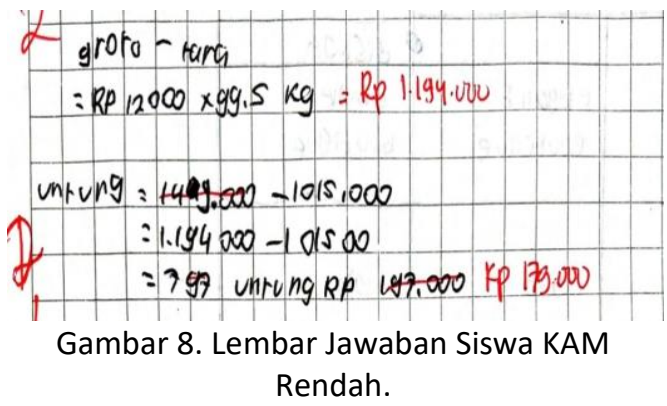

Mosharafa: Jumal Pendidikan Matematika Volume 8, Nomor 2, Mei 2019 Copyright @ 2019 Mosharafa: Jurnal Pendidikan Matematika 
penyelesaian walaupun hasil perhitungan salah (lihat gambar 10)

Berdasarkan gambar 10, siswa KAM sedang telah mampu membuat penyelesaian tetapi perhitungan yang dilakukan salah. Begitupun KAM rendah, perhitungannya juga salah tetapi tahapan yang dilakukan sudah sesuai dengan prosedur (lihat gambar 11).

Berdasarkan gambar 11, siswa KAM rendah telah membuat penyelesaian sesuia dengan prosedur yang ada. Akan tetapi perhitungan yang dilakukannya salah.

Hasil analisi data menunjukkan bahwa PBL memberikan pengaruh yang positif terhadap kemampuan pemecahan masalah siswa. Hal ini sejalan dengan temuan Nadhifah dan Afriansyah (2016) yang menyatakan hal yang sama.

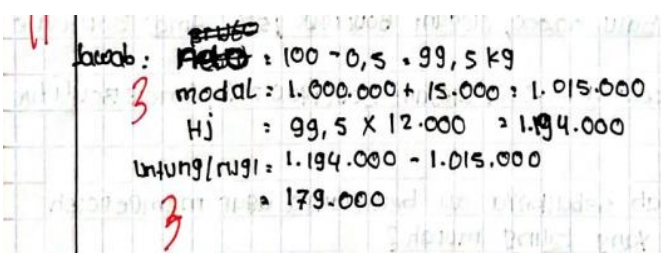

Gambar 9. Lembar Jawaban Siswa KAM Tinggi.

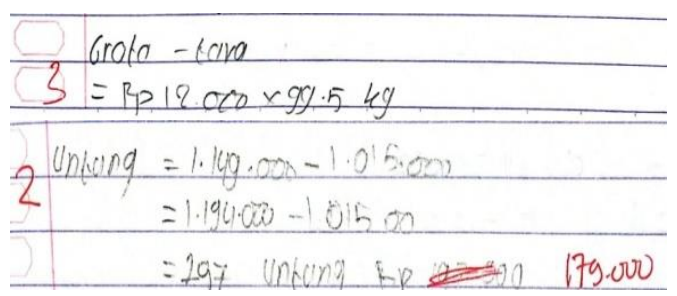

Gambar 10. Lembar Jawaban Siswa KAM Sedang.

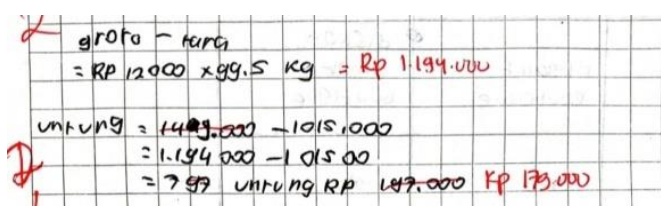

Gambar 11. Lembar Jawaban Siswa KAM Rendah.

\section{Penutup}

Berdasarkan hasil analisis data dan pembahasan maka dapat disimpulkan dari kemampuan pemecahan masalah dengan PBL memberikan pengaruh terhadap kemampuan pemecahan masalah siswa. Pada penelitian ini siswa dikelompok yaitu berdasarkan KAM. KAM merupakan kemampuan awal matematis siswa yang terdiri dari 3 kategori yaitu KAM tinggi, KAM sedang dan KAM rendah.

\section{Daftar Pustaka}

Afriansyah, E. A. (2016). Investigasi Kemampuan Problem Solving dan Problem Posing Matematis Mahasiswa via Pendekatan Realistic. Mosharafa: Jurnal Pendidikan Matematika, 5(3), 269-280.

Amir, M. F. (2015). Prosiding Seminar Nasional Pendidikan: Prosiding Seminar Nasional Pendidikan, (2011), 34-42. https://doi.org/10.3917/rsi.100.0107

Fatimah, F. (2012). Kemampuan Komunikasi Matematis dan Pemecahan Masalah melalui Problem Based-Learning. Jurnal Penelitian dan Evaluasi Pendidikan, 16(1), 249-259.

Gunantara, G., Suarjana, M., \& Riastini, P. N. (2014). Penerapan Model Pembelajaran Problem Based Learning untuk Meningkatkan Kemampuan Pemecahan Masalah Matematika Siswa Kelas V. Jurnal Mimbar PGSD Universitas Pendidikan Ganesha, 2(1), 1-10. https://doi.org/10.1073/pnas.070399 $\underline{3104}$

\section{Mosharafa: Jumal Pendidikan Matematika}


Iskandar. (2009). Metodologi Penelitian Pendidikan dan Sosial (Kuantitatif dan Kualitatif). Jakarta: Gaung Persada Press.

Muliyardi. (2002). Strategi Pembelajaran Matematika. Padang: Universitas Negeri Padang.

Nadhifah, G., \& Afriansyah, E. A. (2016). Peningkatan Kemampuan Pemecahan Masalah Matematis Siswa dengan Menerapkan Model Pembelajaran Problem Based Learning dan Inquiry. Mosharafa: Jurnal Pendidikan Matematika, 5(1), 33-44.

Rusman. (2013).

Model-model

Pembelajaran Mengembangkan

Profesionalisme Guru. Jakarta: RajaGrafindo.

Schunk, D. H. (2012). Teori Pembelajaran: Perspektif Pendidikan. Yogyakarta: Pustaka Belajar.

Sugiyono. (2011). Metode Penelitian Kuantitatif, Kualitatifdan $R$ \& $D$. Bandung: Alfabeta.

Sundayana, R. (2016). Kaitan antara Gaya Belajar, Kemandirian Belajar, dan Kemampuan Pemecahan Masalah Siswa SMP dalam Pelajaran Matematika. Mosharafa: Jurnal Pendidikan Matematika, 5(2), 75-84.

Suprihatiningrum, J. (2013). Strategi Pembelajaran Teori dan Aplikasi. Jogjakarta: Ar-RuzzMedia

Sumartini, T. S. (1981). Peningkatan Kemampuan Penalaran Matematis Siswa Melalui Pembelajaran Berbasis Masalah. Mosharafa: Jurnal Pendidikan Matematika, 4(1), 1-10. http://dx.doi.org/10.31980/mosharaf a.v4i1.239.g244
Utami, R. W., \& Wutsqa, D. U. (2017). Analisis kemampuan pemecahan masalah matematika dan self-efficacy siswa SMP negeri di Kabupaten Ciamis. Jurnal Riset Pendidikan Matematika, 4(2), 166. https://doi.org/10.21831/jrpm.v4i2.14 897

\section{Riwayat Hidup PenUlis}

\section{Rini Sri Putri.}

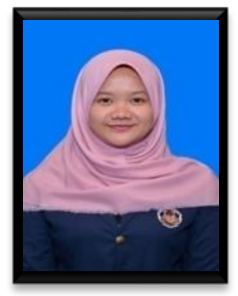

Lahir di Koto Alam, 11 April 1996. Studi S1 Pendidikan Matematika STKIP PGRI SUMBAR, lulus tahun 2019.

Mulia Suryani, M.Pd.

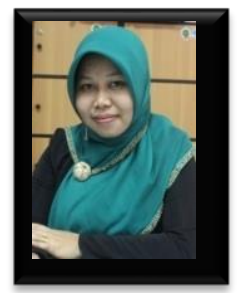

Lahir di Padang, 12 November 1987. Dosen tetap yayasan di STKIP PGRI SUMBAR. Menjabat sebagai Lektor/Penata di Program studi pendidikan matematika Studi S1 Pendidikan Matematika STKIP PGRI SUMBAR, lulus tahun 2009. Studi S2 Kosentrasi Program studi pendidikan matematika. Studi S1 Pendidikan Matematika STKIP PGRI SUMBAR, lulus tahun 2009. Tahun 2010 melanjutkan studi S2 bidang Kosentrasi pendidikan Matematika Pasca Sarjana UNP, lulus tahun 2012.

\section{Lucky Heriyanti Jufri, S.Si, M.Pd.}

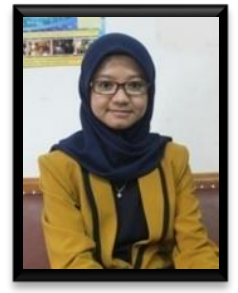

Lahir di Padang, 12 Agustus 1987. Dosen tetap yayasan di STKIP PGRI SUMBAR. Studi S1 Pendidikan Matematika di Universitas Pendidikan 